\title{
THE ROMA IN NEW MILLENNIUM ITALIAN FICTION FILMS: DISSENSUS, LIMINALITY, EMANCIPATION
}

\author{
William Hope \\ University of Salford, UK
}

The Roma endow films with a strong political resonance through their exposure to micro- and macro-level discrimination and reactionary populism in contemporary Italy. A socio-political evolution can be traced in the way new millennium Italian fiction films have depicted the Roma. Early $21^{\text {st }}$ century films were compromised by an ambivalence stemming from an outwardly progressive, 'ethical', and denunciatory impetus that was vitiated by a hegemonic, ethnocentric Italian mindset and an emphasis on tropes of Roma criminality. However, recent works including Laura Halilovic's lo, rom romantica overcome this ambivalence through emancipatory impulses that reflect Jacques Rancière's concept of dissensus - a disruption of society's 'natural' political order and public spaces by those who have not been considered as political beings. Ernst Bloch's writings on the utopian Not-YetConscious also shed light on recent cinematic visions of progressive future configurations for the Roma within the polis, the films' female protagonists occupying liminal positions between Roma and Italian culture.

KEYWORDS: Roma, criminality, Rancière, dissensus, liminality, emancipation

Substantial historical, linguistic and DNA evidence suggests that today's European Roma communities originated in northern India; they began an exodus into areas including Armenia in the $11^{\text {th }}$ century as a consequence of incursions by the Ottoman Turks into Asia, and arrived in central Europe by 1400 AD. ${ }^{1}$ Recent estimates put Italy's Roma population at around $180,000^{2}$ - a significant yet voiceless and marginalized presence that polarizes public opinion, and the Roma's societal status is reflected in the mode and extent of their representation within new millennium Italian cinema. Over thirty documentaries, often low-budget, socially committed work, have been dedicated to the Roma since $2000,{ }^{3}$ but by contrast the number of fiction films featuring them - even in fleeting, secondary roles - remains in single figures. The obvious inference is that the Roma, as narrative subjects, are viewed with caution in the context of commercial cinema's profit imperative.

Notable precursors of the $21^{\text {st }}$ century feature films analysed in this essay include Allullo drom (Tonino Zangardi, 1992), which depicts an encounter between a 
travelling Roma community and a group of young communists in 1950s Tuscany, and Un'anima divisa in due (Silvio Soldini, 1993), a road movie portraying the elopement of a disillusioned Italian store detective, Pietro (Fabrizio Bentivoglio), and Pabe (Maria Bakò), a Roma woman subjugated by her own community and by Italian society. New millennium films have depicted Roma characters in various cameo roles, including the gypsy community to which Antonio (Antonio Albanese) turns for a valuation of a stolen jewel (La lingua del santo, Carlo Mazzacurati, 2000); the Roma youths with whom an Albanian boy, Saimir, briefly associates in a context of escalating delinquency (Saimir, Francesco Munzi, 2004); and the young Roma girl, Astra, who accepts a lift from Giulia (Valeria Golino) and her foster child Mario, to evade an undefined, oppressive presence within the Neapolitan metropolis ( $\mathrm{La}$ guerra di Mario, Antonio Capuano, 2005).

The Roma feature in more substantial roles in Prendimi e portami via (Tonino Zangardi, 2003), the narrative centring on the bond between an adolescent Roma girl, Romana, and her school friend Giampiero, an Italian from a local housing estate whose community clashes with the nearby Roma encampment. Sotto la stessa luna (Carlo Luglio, 2006) depicts the existential and economic struggles of a Roma community within an area of Naples dominated by the Mafia. Dimmi che destino avrò (Peter Marcias, 2012) portrays the uneasy rapport between Alina, a Roma woman who works for a humanitarian organization, and Giampaolo, an Italian police inspector who investigates an apparent kidnapping in Alina's community. Io, rom romantica (Laura Halilovic, 2014), is a coming-of-age comedy that outlines the strategies adopted by young Gioia to resist the diktats of her Roma family and also those of Italy's consumer society. ${ }^{4}$

The Roma endow films with a strong political resonance through their exposure to prejudice fermented by the Italian State, its forces of order and its media lackeys. This essay contends that a socio-political evolution can be traced in terms of the way new millennium films have depicted the Roma. Early $21^{\text {st }}$ century films up to and including La guerra di Mario (2005) - were often compromised by an ambivalence stemming from a hegemonic, ethnocentric Italian mindset that tended to vitiate an outwardly progressive, 'ethical', and sometimes denunciatory impetus. In exploring the Roma's compound marginalization, these films revisited scenarios delineated in Kimberlé Crenshaw's theories of intersectional subordination (1993) ${ }^{5}$ to denounce, for example, the dual scourges of racism and patriarchy to which Roma women are subjected. This was a justifiable approach, because the Roma had been bypassed by the rights movements of the $60 \mathrm{~s}$ and $70 \mathrm{~s}$ and by the identity politics of the $80 \mathrm{~s}$ and beyond. It should also be acknowledged that early $21^{\text {st }}$ century cinematic fiction began to outline nascent forms of micro-level interaction between the Roma and individual non-Roma, instantiated in Prendimi e portami via and La guerra di Mario by scenes in which Romana and Astra enjoy moments of emancipation in the company of Italian characters. 
However, when analysing this filmic work, it is important to be aware that 'prevailing structures of domination' can 'shape various discourses of resistance'. ${ }^{6}$ In the first part of this essay it will be suggested that early new millennium films, from La lingua del santo to La guerra di Mario, are characterized by the recurrence of tropes of Roma criminality, and those of Italian males proactively engaging with Roma females - and benefiting from this interaction - rather than vice versa. As a consequence, historic, hegemonic ideologies are inadvertently reinforced, and these scenarios are often underpinned by realist aesthetics that enmesh the Roma within the poverty imposed on them by the existing socio-economic order. By contrast, more recent works including Luglio's Sotto la stessa luna and Marcias's Dimmi che destino avrò reconfigure the issue of criminality to highlight the injustice and illegality of aspects of the politico-economic treatment of the Roma by the Italian authorities. Dimmi che destino avrò and Halilovic's recent, semi-autobiographical lo, rom romantica also feature more nuanced and unambiguously progressive depictions of the Roma's cinematic (and real-life) evolution across the changing spectrum of working class identity. These two films' representations of the Roma move them towards Žižek's categories of 'intellectual labourers' and 'the old manual working class', and away not only from their traditional role as 'the outcasts' 7 but also, importantly, from any association with delinquency.

The films by Marcias and Halilovic overcome the ambivalence that undermined the political and aesthetic effectiveness of earlier Roma films through a series of emancipatory impulses that reflect Jacques Rancière's concept of dissensus. Significantly, the two films identify Roma women as potential catalysts for change within their communities, and their proactive incursions into Italian society subvert the narrative paradigms of earlier films that relegated them to subordinate, passive roles. Dissensus involves a physical and vocal disruption of society's 'natural' political order and public spaces by those who have hitherto been silent and not considered as political beings. Political acts, in Rancière's terms, occur 'when the boundary separating those who are born for politics from those who are born for the 'bare' life of economic and social necessity is put into question'. ${ }^{8}$ He considers the realms of politics and aesthetics to be eminently disruptable by dissensus, with art forms possessing infinite potential to invert the existing social order. The latter section of the essay examines how the manifestations of dissensus within Dimmi che destino avrò and lo, rom romantica develop into a progressive vision for the Roma within the notion of the polis, as the female protagonists occupy liminal positions between Roma and Italian culture. In this context, the essay conjoins Rancière's thinking with recent scholarship that has revisited Ernst Bloch's writings on cinema, ${ }^{9}$ Bloch having identified the potential of film to elucidate moments of the 'Not-YetConscious' - fragments that articulate as yet unfulfilled human aspirations through cinema's temporal and spatial fluidity. 

VICTIMS?

The Roma's 'otherness' with respect to the societies in which they settle, and their non-conformity with sociological and political thinking of all persuasions, has engendered a long established association with criminality. Given the Roma's frequent spatial marginalization from mainstream society and their exclusion from the rights enjoyed by what Rancière terms the 'ethnos' of a given polis who all share similar origins and outlooks, ${ }^{10}$ only a minimal effort is required on the part of opportunistic institutions to transform this neglect and ostracism into persecution. The construction of the notion of Romani communities as a 'race of criminals' was a factor in the genocide of European Roma under Nazism. ${ }^{11}$ Similar presuppositions can be traced back to the Enlightenment and social Darwinism, and in an Italian context, Sigona and Trehan note how the writings of the anthropologist Cesare Lombroso linked social deviance and racial identity with the inference that gypsies 'were by nature predisposed to crime'.12 They also cite a statement from 1852 in which the Home Office minister, Giovanni Galvagno, argued in favour of keeping gypsies under surveillance. In the $21^{\text {st }}$ century, the Roma continue to run a high risk of criminalization as a consequence of the tendency of Italy's political institutions to target them for special police scrutiny; phenomena such as the Berlusconi administration's Emergenza Nomadi in 2008, which involved the fingerprinting and profiling of thousands of Roma and the searching and closure of camps, contributed significantly to the negative stereotyping of Roma communities.

Given the relatively uncontested circulation of these accumulated historical narratives linking the Roma with illegality, it is significant how many early new millennium Italian films implicitly propagate similar notions. One strand of the problem centres on the use of the Roma in minor roles in which they assume the traditional function of secondary film characters, that of contextualizing a protagonist's given qualities. These interactions invariably establish male Roma characters as predisposed to levels of deviousness and aggression that surpass those of the non-Roma protagonist who interacts with them. An early film like Un'anima divisa in due emphasizes, through eye contact between Pietro and the male 'keepers' of Pabe, who is forced to beg on the streets, that he would be unwise to challenge their treatment of her. Similarly, in Prendimi e portami via, Giampiero's attempt to prevent Romana from being driven away to an arranged marriage results in a brutal assault on him by a Roma man. Even in the context of the comedy-drama La lingua del santo, the Roma's function is similar. Much of the humour - in the sequence in which Antonio takes a stolen precious stone for valuation by local Roma - originates from the slippage between traditional myths of gypsy clairvoyance and insight and a more modern 'hustler' mentality tending towards the exploitation of any lucrative opportunity. The two Roma characters, Krondano and his wife, oscillate in an arch, comic manner between the two modes of behaviour as they examine the jewel. In terms of comic theorization, Antonio is the gullible alazon whose 
deficiencies generate humour when they collide with an external, worldly normality. However, in this case, the yardstick of 'normality' is constituted by the opportunistic Krondano and his partner who predictably appropriate the jewel. Mazzacurati contrasts Antonio's naïve attempts at criminality with the ostensibly more affluent and criminally competent Roma, and while dark humour is elicited by signalling the scale of Antonio's ineptitude and spiralling poverty by visibly positioning him below the Roma socio-economically, this approach ultimately perpetuates the hegemonic assumption of immanent Roma delinquency.

In terms of cinematic tropes of criminality, Munzi's Saimir constitutes a particularly deleterious representation of the Roma within new millennium Italian cinema. As Áine O'Healy, referencing Derek Duncan, suggests, the film's narrative momentum centres on distinguishing the qualities of the Albanian Saimir from the different strands of criminality that form the film's backdrop. ${ }^{13}$ But the viewer's unequivocal allegiance to Saimir is achieved partly by consigning the film's Roma characters to the nether regions of the viewer's 'hierarchy of preference' in the context of Murray Smith's observations concerning the way film narratives marshal a spectator's sympathies for or against specific characters. ${ }^{14}$ Aesthetically unattractive youths were cast in these roles, their characters embracing values and expedients that Saimir shuns, and they are entrapped within squalid, realist visuals in a narrative that is structured to portray thefts occurring within ninety seconds of the Roma materializing on screen. Munzi's mise-en-scène in the sequence of a burglary at a local villa debases the Roma further, as Saimir's alienated, aloof passiveness is contrasted by actorly movement that accentuates the Roma's almost animalesque, cross-frame foraging through the villa.

Although certain films are characterized by a greater political sensitivity towards the problems faced by the Roma in terms of urban integration - works such as Prendimi e portami via, for example, which capture the attritional dynamic between the Italian proletariat and the Roma at the peripheries of Italy's metropolises - they are undermined by their inability to identify and resist ideological myths linked to illegality. Prendimi e portami via depicts the escalating guerra tra poveri exacerbated by a populist, xenophobic synergy between local level agitators and State policies championed by government coalition partners such as the Lega Nord. This form of antagonism culminated in the punitive attacks on Roma camps that occurred in Turin in 2011. ${ }^{15}$ Although the film's cinematic recreation of one such camp raid is an important depiction of a phenomenon that no documentary filmmaker is ever likely to capture, the film is compromised by its narrative premise, a gratuitous theft of goods from a van owned by an Italian - almost certainly perpetrated by Roma - an action that opens the spiral of violence.

When early new millennium Italian cinema's treatment of the issue of the Roma and criminality is contextualized within post-war European film, its difficulties in distancing itself from hegemonic suppositions of Roma deviancy are not unique. Caterina Pasqualino questions the implications of the romanticized urban/rural 
polarization that evolves in Los Tarantos (Francisco Beleta, 1963); $;^{16}$ the film contrasts affluent but corrupt urban gypsy horse traders with their altruistic counterparts from the more countrified city peripheries. Emir Kusturica's Time of the Gypsies (1989) also draws censure from Pasqualino for adopting a classic nonRoma view of the Roma's purportedly innate delinquency, ${ }^{17}$ as a Roma youth is absorbed into an urban vice ring. A similar criticism is levelled at Kusturica's Black Cat, White Cat (1998) by Nikolina Dobreva. The critic challenges Kusturica's apparent socio-political decontextualization of the Roma's marginalization and also the implication that their delinquency is linked to 'their own flawed character'. ${ }^{18}$ Dina lordanova's focus shifts towards the role of the punitive State as she analyses several late 20th century Eastern European works, including the Czech film Marian (Petr Václav, 1996). The narratives of these films depict 'Roma adolescents whose lives revolve around petty crime followed by excessive punishment, tracing an unavoidable and socially conditioned pathway from juvenile delinquency to prison'. ${ }^{19}$ Dobreva's accusation of socio-political decontextualization is undoubtedly relevant to the early $21^{\text {st }}$ century Italian works examined in this section and it can be extended to include the films' omission of historico-cultural questions. Unlike work by the Algerian-Romani film-maker Tony Gatlif, in which Romani music and culture are pivotal - films which also reference the 'forgotten' Roma genocide during the 1940s (Latcho drom (1993), Swing (2002), Korkoro (2009)) - early new millennium Italian cinema tended to represent the Roma as having always been a feature, albeit marginalized, of Italy's post-industrial urban landscapes.

However, Sotto la stessa luna and Dimmi che destino avrò marked a shift in perspective with regard to the theme of the Roma and delinquency. They adopted a discernibly more Marxist criminological view than their predecessors, examining the implications of excluding sections of the population from employment within capitalist society and, in the case of Dimmi che destino avrò, questioning the fundamental notion of criminality as defined by the hegemonic bourgeois State. In contrast with lordanova's analysis of the punitive legal system in Eastern European contexts, Sotto la stessa luna depicts the near abandonment of metropolitan areas such as Scampia in Naples by Italy's institutions; these power vacuums are filled by mafia organizations who become the main socio-economic influence. Using the narrative device of the release from prison of Pavel, a Roma youth, the film illustrates his attempts to re-establish an income within the narrow interstices left by the interests of the local mafia, whose protection rackets are depicted as an economic given. Pavel and his Roma colleague Oliver sell roses in restaurants and wash car windscreens, but in the absence of any remunerative and dignified employment, Pavel is inexorably drawn towards committing theft in the Camorra's territory. The film's tragic finale, based on real-life occurrences, ${ }^{20}$ depicts the Camorra shooting two Roma in an orchestrated show of force; this prompts the community to abandon the camp in the absence of any police protection. Few films illustrate the compound marginalization endured by the Roma more effectively than Sotto la stessa luna; it is an impassive socio-economic analysis of the minimal life choices available within 
neoliberal regimes, and distances itself from any ideology associating the Roma with inherent delinquency.

The focus of Dimmi che destino avrò is also counter-hegemonic, addressing notions of crime but directing its attention towards the State as the perpetrator of illegal actions during the Emergenza Nomadi which began in May 2008. While the narrative initially centres on a police investigation into a putative kidnapping at a local camp, it soon transpires that such occurrences - in Roma culture - are not uncommon, as couples sometimes elope to avoid paying dowries. Therefore, as its theoretical premise, the film reiterates the recourse of majority societies to historical prejudice in an attempt to comprehend subaltern cultural practices that fall beyond the taxonomy of 'established' social behaviour. Given its setting in an authorized, equipped camp in contrast to the dilapidated informal camps situated near Italy's motorways and refuse tips, ${ }^{21}$ Dimmi che destino avrò is also the first Roma film to evacuate the question of economic poverty (and concomitant issues of economic crime which invariably coalesce around Roma characters in less ideologically robust films) from its narrative. It thereby enables a more focused dissection of the political, social and cultural relations between the Roma and the Italian institutions. A realist aesthetic is used, not - as in earlier new millennium films - to transfix the Roma within environmental destitution, but in order to subvert viewer assumptions and denounce institutional oppression. This is instantiated during the film's dramatic reconstruction of an Emergenza Nomadi camp sweep as handheld camera work and open framings depict the police passing in and out of shot, and prolonged POV shots replicate Alina's dismayed perspective.

The Emergenza Nomadi endowed the Italian State with a proactive agency, enabling it to exert power over an objectified minority. High visibility micro-level lawand-order drives that target the vulnerable - rather than more justifiable dragnets of the mafia-run strongholds within Italy's metropolises - generate short-term electoral approval, and 'maintain the public focus on the repressive aura of such legislation and not on its contradictions' ${ }^{22}$ But Dimmi che destino avrò diametrically moves its focus from a micro-level 'crime' perpetrated by community outsiders - Giampaolo is also warned to watch his wallet by the smiling procuratore who hands him the case to an examination of macro-level human rights abuse resulting from a measure that the Consiglio di Stato subsequently decreed as illegitimate in 2011. The Corte di Cassazione upheld this judgement in 2013, and this has led to successful compensation claims by Roma whose biometric data were taken. ${ }^{23}$ New millennium Italian cinema has therefore demonstrated an increasing sensitivity towards the socio-political determinants forcing the Roma into the role of outsiders, and it has undergone a perspectival shift away from notions of intrinsic Roma delinquency based on a presumed exploitation of other Roma and on thieving - towards an awareness of the way political institutions have discarded philosophies of social assistance in favour of neoliberal 'crime control' or 'exclusionary' models. ${ }^{24}$ These 
approaches instrumentalize people's fear of crime in order to validate increasingly repressive measures against marginalized groups such as the Roma.

EARLY NEW MILLENNIUM CINEMA: PATRIARCHY, MELODRAMA AND THE
ENRICHMENT OF MAJORITY SOCIETY

Together with notions of criminality, a recurring locus of interest for contemporary Italian film-makers has been that of female Roma. Recent work featuring female Roma characters can also be divided into two distinct phases, mirroring the preceding analysis of new millennium cinematic explorations of the Roma/delinquency paradigm. The first phase - the focus of this section - is from Un'anima divisa in due to La guerra di Mario, and it is characterized by contradictory progressive and reactionary impulses towards Roma women and their communities. The second phase - from Sotto la stessa luna to the present day and the most recent Roma film, lo, rom romantica - is distinguished by a more coherent, emancipatory momentum through which Roma women assume assertive and abrasive positions with regard to their own communities and to Italian society. With reference to Christine Mohanty's essay 'Cartographies of Struggle: Third World Women and the Politics of Feminism', David Harvey reiterated the importance of ascertaining the identity and agenda of the individuals who create knowledge about subjugated and colonized peoples, ${ }^{25}$ and it is still essential to identify where residual, hegemonic, Eurocentric perspectives distort cinematic narratives. The sexualisation of the female 'other' is a historically engrained distortion, and Roma women have featured within this phenomenon. In his discussion of the male erotic imaginary in the $20^{\text {th }}$ century, lan Hancock traces an orientalist turn, in terms of desiring and recounting intimacy with Romani women, in correspondence between members of the Gypsy Lore Society in 1908 who were predominantly bourgeois, white and male. ${ }^{26}$ Domnica Radulescu observes that Roma women have been 'equally idealized and demonized' through the centuries, associated (in Western eyes) with passion and sexual freedom compared with their European counterparts, while paradoxically enduring repressive patriarchal practices within their own communities. ${ }^{27}$ Recontextualizing the discourse with regard to contemporary cinematic representations of female Roma, Dina lordanova - without, however, specifying a distinct body of work - suggests that their enigmatic sexuality is 'perpetually desirable for the dominant 'white' ethnicity [...] Clearly, these plots have more to do with the trouble that inhibited 'white' Western sexuality experiences in accommodating its own 'dark' passions than with the real Romani culture'. ${ }^{28}$ Given that the directors of Roma fiction films produced in Italy since the 1990s have been male Italians - Laura Halilovic's Io, rom romantica excepted - Hancock's assertion that 'Romani identity still remains to a great extent controlled by the non-Romani world' is undeniable. ${ }^{29}$ The question, then, of why female Roma, and also female 
Roma adolescents and children, occupy such pivotal roles in contemporary films, requires consideration.

Kimberlé Crenshaw developed her seminal concept of 'sexual stratification' within a broader analysis of gender relations within hegemonic societies. She asserted that 'White men predominate as agents of social control. Therefore, they have the power to sanction differentially according to the perceived threat to their favoured social position'. ${ }^{30}$ Within such societies, women are implicitly viewed as 'the valued property of the men of their own race' and any unsolicited interaction, especially sexual, between non-white males and white women 'threatens the white man's 'property rights' and his dominant social position'. ${ }^{31}$ By contrast, any sexual intent from white males towards non-white females is perceived as non-threatening to the status quo. With the exception of Zangardi's Allullo drom, it is significant that nearly every form of character interaction in Italian Roma films is based on a male Italian/female Roma nexus. In an early film like Un'anima divisa in due, it is not problematic to suggest that an understated orientalist curiosity animates the lingering medium shots and close-ups of the enigmatic Pabe during her journeys with Pietro. When the nexus shows rare signs of inversion, as in Sotto la stessa luna when Oliver makes repeated eye contact with the girlfriend of a mafia boss, the threat of exemplary punishment is manifest, and duly materializes with the shooting of two Roma community members. But a more nuanced reading is required to delineate the dramatic function of female Roma characters within their respective films.

In many ways, Roma females constitute an ideologeme, in Fredric Jameson's words - a point of conflict within texts where reactionary forces clash with emancipatory impulses; a battleground where two contrasting world views are distilled. ${ }^{32}$ Often, the progressive impetus that vivifies female Roma characters within early new millennium films is vitiated by the disclosure of implicitly prejudicial or hegemonic credences with regard to the Roma community as a whole; Crenshaw's warning concerning the way 'prevailing structures of domination shape various discourses of resistance' is again pertinent. ${ }^{33}$ Several films illustrate the overlapping systems of subordination that penalize Roma women both for their gender and race, and the films make laudable attempts to elucidate parallel systems of oppression in the gagé or non-Roma world for the sake of balance. In Un'anima divisa in due, Pabe's oppressed existence in the Roma community is not resolved by her assimilation into Italian society as a hotel worker, as indicated by an attempted sexual assault by a male guest and then by an anonymous tip-off to the hotel about her racial origins that results in Pabe's dismissal. Prendimi e portami via features similar parallels between Romana's patriarchal household and Giampiero's stubborn, reactionary father who eventually collaborates with xenophobic local figures. In $\mathrm{La}$ guerra di Mario, the Roma girl Astra, who accepts a lift from Giulia and Mario, is perturbed at being shadowed by a nearby car; minutes later, an analogous sense of surveillance occurs when Giulia's partner Sandro tersely demands an explanation after hearing the trio's laughter on his cell phone. While first world anthropological 
value systems have been criticized for 'turn(ing) a blind eye to patriarchal practices, excusing them as the "other culture", ${ }^{34}$ these films unquestionably confront the issue directly. Their treatment of the question, however, fails to distinguish between patriarchy and male delinquency. The portrayals of Pabe and Astra imply that they are being exploited, while the way Romana's father cedes her to a colleague in an arranged marriage to settle a gambling debt, also denotes an irremediably deviant value system.

The progressive impulse that draws film-makers to position female Roma at the heart of their narratives is arguably linked to a sense that many male Roma have already been 'lost' by internalizing the worst aspects of the hegemonic society that surrounds them. Male Roma compensate for their marginalized social position in Italy by ensuring that they continue to occupy authoritarian and patriarchal roles within their families and communities. Even Laura Halilovic, a relatively empowered female Roma film-maker, uses reiterated low-angle close-ups of Gioia's overbearing father in lo, rom romantica to convey a sense of continuing oppression within Roma families who have ascended to the roles of 'intellectual labourers' or 'the manual working class' in Žižek's terms. ${ }^{35}$ On the basis of the films discussed so far, it has been demonstrably difficult for film-makers to develop narratives that are sufficiently nuanced to avoid an incipient criminality taking root within the marginalized destitution of the poorer Roma. Many male Roma characters in early new millennium films simply reproduce capitalism's exploitative structures in the meagre, peripheral spaces that are left to them by neoliberal entrepreneurship and by crime syndicates. Equally, because economically stable Roma, including Gioia's father Armando, are absorbed by manual work and satisfied with their private patriarchal fiefdoms, there is little likelihood of them becoming the agents of politically progressive actions, in Rancière's terms, where hitherto marginalized people 'occupy the space-time of political things [...] Politics occurs when those who have 'no time' take the time to front up as inhabitants of a common space'. ${ }^{36}$ Female Roma characters, therefore, are more politically and cinematically engaging, given their emancipatory potential and also the scale of their gender/racial marginalization which is easily transmuted into the melodramatic narrative mechanisms that underpin sections of mainstream cinema.

Female Roma characters are also, to some extent, mirror images of their male counterparts discussed earlier. While male Roma seem capable of levels of deceit and aggression that exceed those of the non-Roma protagonists who engage with them, the passionate verve that has traditionally animated fictional constructs of Roma women has been distilled into a quick-witted resourcefulness and determination that equips female Roma characters to withstand the ruthlessness of life on the margins of a capitalist society primed to exploit the weakest. Within their respective narratives, the mindset of female Roma characters galvanizes and inspires the alienated non-Roma characters, usually male Italians, who interact closely with them. But structurally and perceptually, most Italian Roma films - 
excluding lo, rom romantica - are anchored to the consciousness of male non-Roma protagonists. The issue of who produces knowledge about subaltern peoples, and with what agenda, is again relevant; in Paloma Gay y Blasco's words, majority society's representations of the Roma 'are instructive in the creation of the identity of the majority Self', and in the cultural narratives recounted about the Roma, 'we find ourselves, our desires, fears and preoccupations, our shared and individual ontologies and existential dispositions'. ${ }^{37}$

In several films, female Roma characters are used to shed light on the desires, qualities and inadequacies of non-Roma protagonists, and they are sometimes deployed as catalysts for change to benefit the dominant ethnic group. This is apparent from early works like Un'anima divisa in due, in which Pietro assimilates a more spontaneous worldview - and a bohemian dress sense - after travelling with Pabe, whereas her assimilation into Italian society fails. It is Romana who broadens the horizons of the passive Giampiero in Prendimi e portami via, proposing various schemes to him to thwart her arranged marriage, and he eventually feels sufficiently galvanized to rescue Romana from her subjugation. Astra's effervescent interaction with Mario in La guerra di Mario implies that the taciturn youngster might - in other circumstances - have found a soulmate for company during the difficult transition to life with foster parents. Similarly, in Dimmi che destino avrò, it is by interacting with Alina that Giampaolo Esposito becomes sensitized to the illegality of the Emergenza Nomadi and withdraws from the operation. Many non-Roma protagonists convey a disorientation experienced by increasingly broad sections of Italian society as they are immersed in neoliberalism's chaotic morass with little political, economic and social stability. The characters reflect Gay y Blasco's notion of the way majority society comprehends its own identity and its fragilities through interaction with the Roma, ${ }^{38}$ who have withstood oppressive conditions for centuries. While there is an underlying implication in early $21^{\text {st }}$ century cinema that the Roma are better equipped to confront the uncertainties of liquid modernity than their Italian equivalents, there is also an inescapable sense that female Roma characters are used to enrich individuals from majority Italian society, with much less narrative impetus being directed towards the exploration of emancipatory possibilities for the Roma themselves.

Together with ethnocentric narrative perspectives that privilege the personal enrichment of the Italian protagonists of early $21^{\text {st }}$ century feature-length fiction, another factor that militates against the envisioning of emancipatory prospects for the Roma - and particularly Roma women - is the undercurrents of melodrama that are discernible in various works. They are often a consequence of the films restricting themselves to emotional explorations of the disempowerment of female adult and child Roma and being politically unable or unwilling to envisage more liberating societal configurations. What Marcia Landy defined as 'a constant struggle for gratification and equally constant blockages to its attainment' and the tendency for narratives to be 'driven by the experience of one crisis after another, crises 
involving severed familial ties, separation and loss', ${ }^{39}$ are mechanisms traceable throughout Prendimi e portami via - particularly in the scenes leading to Romana's arranged marriage - and also at the end of the sequence featuring Astra in La guerra di Mario, as Mario plaintively asks if he can take a photo of the girl before she disappears back into her camp. Similarly, the camp exodus at the end of Sotto la stessa luna, a scene featuring dozens of Roma passing numbly through the frame with their belongings, exemplifies a melodramatic 'disproportion between the weakness of the victim and the seriousness of the danger'. ${ }^{40}$ Nevertheless, this latter film, from 2006, contained narrative elements that were gradually developed into a more assertive Roma identity within later Italian feature films. It referenced real-life initiatives with which the Roma have engaged to combat their marginalization, and the film also envisioned a greater socio-political agency for the Roma predicated on the emancipation of Roma women.

\section{THE CINEMATIC AND BEYOND: DISSENSUS, LIMINALITY AND EMANCIPATION}

Academics and advocacy groups acknowledge the value of the 'social capital' that constitutes the Roma's principal form of intra-group security - the concept of benefitting from community networks that 'may ease an individual's access to employment, housing, funds' and facilitate 'peer-based learning from experience'. ${ }^{41}$ While research has identified the Roma's preference for social interaction within their own ethnic group, ${ }^{42}$ it also emphasizes that they derive notable educational, legal and health benefits from participating in outreach initiatives organized by welfare organizations and individuals from local authority departments. ${ }^{43}$ While new millennium Italian documentaries about the Roma have rapidly assimilated these developing synergies - for example Sastipe - star bene (Carraro et al. 2001) examines the role of Roma women who train to be health visitors in their communities - feature-length fiction has taken longer to liberate itself from the narrative and genre paradigms previously discussed in this piece. However, three recent films, Sotto la stessa luna, and particularly Dimmi che destino avrò and lo, rom romantica, position female protagonists at the heart of their narrative telos. They articulate emancipatory scenarios in which individual Roma can occupy strategic, liminal positions where they are supported by their ethnic networks, while also engaging critically and progressively with Italian society. Inevitably, both on screen and in real life, this necessitates a return to the notion of emancipation via microlevel identity politics.

Sotto la stessa luna includes a sequence in which Franco, an Italian recently released from prison, converses with Samanta, his teenage daughter who lives with her Roma mother in a caravan park on the city limits. Franco is struck by Samanta's commitment to her studies, and the way she diplomatically concludes their 
conversation in order to travel to school reflects a single-minded desire to transcend her marginal, minority position, fulfil her potential and access the civic space that Rancière defines as 'the common'. ${ }^{44}$ The concept of emancipation recurs frequently in Rancière's political writings, the philosopher - in his reflections on possible $21^{\text {st }}$ century configurations of communism - suggesting that emancipation is connected to the 'self-superseding expansion' of the space of the common based on a collective, shared intelligence. ${ }^{45}$ Consequently, emancipation entails 'the appropriation of this intelligence which is one' ${ }^{46}$ Rancière asserts that emancipation tends to be 'transmitted from individuals to individuals' rather than through a logic of aggregation; ${ }^{47}$ this conceptualization of the phenomenon reflects the nature of the real-life advocacy work and training provided by organizations including Italy's Associazione 21 luglio, ${ }^{48}$ and also mirrors the emancipatory impulses located in Dimmi che destino avrò and lo, rom romantica. In Marcias's film, for example, Alina credits her career success to a local educator known only as Anna, who arranged tutorials in Roma camps. Later sequences, including a school prizegiving to celebrate the achievements of Roma children, unveil vistas on the fulfilment of Roma potential that remain invisible within contemporary political and media agendas, and, indeed, within the narratives of early new millennium Italian films.

The cinematic depiction of pathways taken by the Roma towards selfrealization and an integrated societal role constitutes a return to elements that Ewa Mazierska and Lars Kristensen critique in their overview of the postmodern interest in 'marginality, in local and subjective phenomena' and 'small narratives'. Although the postmodern perspective gave voice 'to those whose views were previously suppressed, such as women, people of colour, victims of colonial conquest, sexual minorities and children', ${ }^{49}$ its fragmented approach risked losing sight of larger political projects. Mazierska and Kristensen acknowledge, however, that any such project must never overlook 'the specific and the marginal', ${ }^{50}$ and Rancière also identifies the political salience of the 'singular universal' at a local level; points of conflict occur 'between the structured social body where each part has its place and the 'part with no part' which unsettles this order'. ${ }^{51}$ The socially disenfranchised - of which the Roma constitute a key part - are a constellation of 'singular universals', and Žižek categorizes them as a source of political antagonism that can never be subsumed into ethical debates while there exists 'a State community which perceives the Excluded as a threat and worries how to keep them at a proper distance'. ${ }^{52}$ The Roma, both politically and culturally, require outlets to recount subjective 'small narratives' - on their own terms - as a necessary phase of their process of emancipation, and in order to assume a prominent role alongside Italy's more articulate minority groups. In the context of new millennium films featuring the Roma, it is Rancière's concept of dissensus that mirrors the way in which Alina in Dimmi che destino avrò and Gioia in lo, rom romantica are endowed with political voices that demand to be heard. 
For Rancière, dissensus involves demonstrating that arguments can be presented by unconventional subjects who are 'qualified to argue, over an identified object, to an addressee who is required to 'see' the object and to hear the argument that he 'normally' has no reason to see or hear'. ${ }^{53}$ It is a process based on 'breaking with the sensory self-evidence of the natural order that destines specific individuals and groups to occupy positions of rule or being ruled'. ${ }^{54}$ Once Alina and Gioia move from the domestic sphere and from the spatial marginalization of Roma communities into their roles as an advocate for an international rights group and a film-maker respectively, their discourses concerning the abuse of State power during the Emergenza Nomadi and the ongoing problem of male domination of the female in personal and professional contexts transcend the specificity of the Roma's situation. Here, the Roma embody the 'singular universal' in the sense that certain determinants affecting their lives contain a political resonance that brings majority society issues into sharp focus, ranging from the behaviour of the forces of order during the G8 protests in Genoa in 2001 to the recurring incidents of femminicidio across the peninsula.

Dimmi che destino avrò depicts an element of dissensus centring on individuals being torn 'from their assigned places' and on free expression emanating from new subjects who disrupt established hierarchies and forms of belonging. ${ }^{55} \mathrm{In}$ an inversion of the cinematic trope that frequently depicts non-Roma approaching Roma camps - areas that unfold before the camera as uncharted territory requiring exploration from the non-Roma protagonist almost in an orientalist manner - it is Alina who, in the aftermath of the Emergenza Nomadi camp searches, sweeps into the headquarters where Giampaolo works and berates the Italian police for having targeted the Roma unjustifiably. ${ }^{56}$ The inspector is embarrassed into silence and loses his power of political discourse during the prolonged rebuke, a 'violently poetic displacement of the prevailing relations of speech' via the introduction of 'supplementary speech that is irreducible to the constraints of social place'. ${ }^{57}$ The importance of Alina being able to overcome the issue of Roma voicelessness is also emphasized in an earlier scene as an Italian lawyer, depicted in a court environment as the case for the deportation of a Roma girl is outlined, wearily talks to Alina about the Roma's lack of rights and the weight of institutional prejudice against them. The urgency of developing new generations of articulate, politically aware Roma advocates - similar to the film's innovative, prescient portrayal of Alina - in order to take the Roma community's destiny out of the hands of the dominant society, including those of benevolent but enervated allies like the Italian lawyer, is implicit.

lo, rom romantica, written and filmed by a female Roma director under the aegis of Rai Cinema, charts Gioia's gradual immersion into cinematic culture as a consequence of her admiration for the work of Woody Allen. It constitutes the most progressive configuration of narrative, political and cultural elements to emerge from contemporary Italian cinema's portrayals of the Roma. Any lingering ambivalence generated by male-controlled representations of female Roma as objects of latent 
desire, or as individuals to 'save' from the 'repression' of their communities, as is implicit in Un'anima divisa in due, Prendimi e portami via, and La guerra di Mario, is dispelled by Laura Halilovic's presence behind the camera and by her autobiographical perspective of growing up in Turin and taking possession of the dual cultures, Romani and Italian, that have overwhelmed others like her. Liminal positions, on the margins between cultures, have long attracted academic interest for their emancipatory possibilities, and it is again entirely appropriate to revisit these writings in order to contextualize the Roma within them for the first time. David Harvey (1996) perceptively examined the approaches of Raymond Williams and bell hooks in identifying border positions as critical spaces 'from which to challenge hegemonic discourses'. ${ }^{58}$ Marginality, in this case, can be inverted to become a perspectival advantage enabling individuals to question dominant ideas in adjoining cultures. Williams's 'militant particularism' within borderland spaces centred on an 'actual material place of refuge (either as recorded in memory or in day-to-day active experience), partially outside of the embrace of overwhelmingly powerful social processes and social relations [...] the ultimate refuge of a counter-hegemonic politics that could never be taken away'. ${ }^{59}$ bell hooks's writings shared this constructive perspective on liminality but were also sensitive to the 'silencing' that occurred in her own community, and to the need to find and maintain control of her voice to avoid its subsumption into dominant hegemonies. ${ }^{60}$ Nevertheless, a borderline position rooted in one's own community 'nourishes one's capacity to resist. It offers to one the radical perspective from which to see and create, to imagine alternatives'. ${ }^{61}$

Structurally, Io, rom romantica portrays Gioia's initial criticisms of - and movement away from - the Roma community; her engagement with Italian society, a process during which she rejects its attempts to absorb and commodify aspects of her female Roma identity; and, ultimately, her re-integration within the Roma community on her own terms, having enriched her knowledge with film-making expertise. Gioia becomes a transcultural subject, passing across boundaries of her own volition, and benefitting from the two cultures to achieve self-realization. lo, rom romantica is predicated on dissensus, the hierarchical logic of Roma and Italian culture being systematically disrupted by Gioia. Halilovic uses the comic absurd to critique the patriarchal relations within Gioia's family, as her gormless brother is tasked with chaperoning her during a shopping trip. Gioia's subsequent diatribe questions the legitimacy of this surveillance, her parents' attempts to organize a marriage for her, and her mother's acquiescence to patriarchy. It constitutes an unexpected manifestation of dissensus within the domestic space, an action consisting in:

[S]howing as political what was viewed as 'social', 'economic' or 'domestic' [...] It is what happens whenever 'domestic' agents - women or workers for instance - reconfigure their quarrel as a quarrel concerning the common, that 
is, concerning what place belongs or does not belong to it, and who is able or unable to make enunciations and demonstrations about the common. ${ }^{62}$

Gioia's verbal directness and occupation of the 'common' is one of the few qualities to capture the attention of the cynical, world-weary mechanic Alessandro, a figure who is notably less influential than equivalent Italian male characters in early new millennium cinema and who metaphorically disappears from the narrative before Gioia decides - alone - to travel to Rome to experience Cinecittà and seek contacts in the world of film-making.

The sense of Gioia maintaining control of her own identity, voice and narrative, while evaluating the mechanisms of Italian society and culture, is constant. A brief role as an extra in a commercial enables her to examine and then rebuff a process entailing the commodification of her outward appearance, but the authoritative manner of the commercial's female assistant director fuels Gioia's imagination. Similarly, she frequents a local Italian documentarist, Enrico, but soon withdraws from being the sociological subject/object of one of his projects. This is a classic example of 'supposedly emancipatory discourses shaped at the center' colonizing discourses that appropriate and retell subaltern stories for their own advancement and to reaffirm hegemonic dominance. ${ }^{63}$ Instead, Gioia accesses collective knowledge ${ }^{64}$ to acquire technological familiarity with film cameras, and this enables her to maintain control of her life narrative and attain emancipation without requiring a 'guide' from any existing, dominant elite. Rancière warns that this is frequently 'the way of infinite reproduction of inequality in the name of a promise of equality' ${ }^{65}$ and offers an acerbic interpretation of how postmodernism became 'a smokescreen hiding the transformation into ethics and the pure and simple inversion of the promise of emancipation' ${ }^{66}$ As regards the Roma, this is relevant both within their communities where amenable interlocutors are invited by the Italian authorities for dialogue and to assist with the distribution of the notional 'benefits' devolved by the State to the Roma, ${ }^{67}$ leaving the status quo untouched, and also within the State's own hegemonic superstructure where certain co-operatives and contractors derive considerable advantages from the contracts awarded for providing the Roma with accommodation and services. ${ }^{68}$

Gioia's advancement from the domestic sphere into the civic space of the common to appropriate and personalize one of the dominant society's cultural forms - cinema - together with the aesthetics and signifiers used by Halilovic in the film itself, indicates a renewed sensitivity towards culture as a realm that the Roma have historically utilized, and continue to use, as a channel of self-expression. Again, this exemplifies the way Italian feature-length fiction has taken longer than the documentary genre to register the emancipatory potential of cross-community cultural initiatives involving the Roma. Music (Miracolo alla scala, Claudio Bernieri, 2011), art (Immaginario rom - artisti contro, Domenico Distilo, 2011), and cinema ( $\mathrm{La}$ palestra, Francesco Calandra and Maria Grazia Liguori, 2012) provide terrain for the 
Roma to interact with the more enlightened members of the societies in which they reside. In his essay, 'The Paradoxes of Political Art', ${ }^{69}$ Rancière notes art's potential as a dissensual activity capable of subverting hegemonies by 'proposing to politics rearrangements of its space' through 'new possibilities of subjective enunciation', ${ }^{70}$ a process that can reconfigure the excluded in more central, proactive roles. In addition, within what Rancière terms art's 'aesthetic regime' is the potential to use poetic imagery to move beyond mere mimesis - forms of realism which, in early new millennium films, entrapped the Roma within the impoverished economic parameters established by the State. In contemporary contexts of political consensus in countries like Italy where political agency and discourse are restricted to privileged members of society with established roles, the importance of culture in redefining 'the common of a community, to introduce into it new subjects and objects, to make visible what had not been', ${ }^{71}$ and in using innovative visual signifiers to herald these changes, is considerable.

Early sequences of 10 , rom romantica, set in the apartment of Gioia's family, are reminiscent of the colourful domestic interiors of Almodòvar's early work, but Gioia's (and, in real life, Halilovic's) gravitation towards the films of Woody Allen holds a greater significance. Gioia's initial fumblings with a film camera on the streets of Turin's Falchera district are represented via long duration POV takes through a viewfinder, and a sense of subjective belonging and possession rapidly permeates the images of quiet nocturnal streets. There is a discernible parallelism with the profound attachment to Manhattan that emerges in Allen's night-time depictions of the area. Describing Allen's affinity with his urban environment, Patricia Kruth suggests that 'however distressing the situation, the stability of the relationship between the Woody Allen protagonist and his familiar surroundings is never at stake; the city is his'. ${ }^{72}$ The assimilation of Falchera into this new subjectivity within mainstream Italian cinema - that of a Roma woman who, through the cypher of her film protagonist, takes possession of one of the dominant society's cultural media and references the work of an established director to stake a personal, territorial claim to a part of northern Italy as her home - is profoundly resonant politically, considering the extent of the Roma community's marginalization and the difficulties faced by Italian-born Roma in obtaining citizenship. ${ }^{73}$

Rancière's work on the emancipatory potential of the aesthetic has a theoretical antecedent in the writings of Ernst Bloch, who was drawn to cinema's transformative powers. Bloch elucidated 'what he calls the Not-Yet-Conscious in this cultural form' which had a unique capability of articulating 'human hopes, aspirations, longings and desires'. ${ }^{74}$ Johan Siebers suggests that Bloch was inspired by art's premonitions of future occurrences and its 'utopian core', ${ }^{75}$ and Bloch specifically reflected on the nature of time in Chaplin's film narratives, 'where the old vanishes away while the new has not yet become clearly evident; and where that which is best $[\ldots]$ is likewise travelling, passing us by, unrecognized'. ${ }^{76}$ lan Fraser analyses Bloch's interest in the process of humanity 'actively comprehending itself' and his 
concept of 'subjective hope', where individuals focus on possibilities that have not yet materialized, but which can be concretely realized and grasped. ${ }^{77}$ Halilovic's film transcends its modest budget, suburban setting, and sometimes the cinematic space itself, with moments such as these, and it is not erroneous to ascribe an authorial intentionality to sequences where an assertive $21^{\text {st }}$ century female Roma mindset engages directly with viewers, beyond the 'fourth wall'.

This is exemplified on two occasions, the first prefiguring Gioia's journey to Rome to follow her passion for cinema. She exits her apartment block, strides towards the camera, and smiles assuredly in medium close-up - subverting a range of behavioural norms associated with Roma women and presaging greater control over her identity and destiny. Cinema's spatial elasticity also enables Halilovic to move from the mimetic towards the poetic by opening up a seemingly utopian space within a painting in Gioia's family's living room. The mise-en-scène within this framewithin-a-frame depicts a female figure advancing along an avenue of blossoming trees before melting into the distance. The metaphorical implication of new, but as yet undefined horizons is undercut by a backward zoom towards the reality of the living room, where a Roma couple have brought their son to be assessed as potential husband material by Gioia's parents, but since the scene is inserted shortly after Gioia's gaze to camera, the sense is of a transient and monodimensional present ineffectually holding at bay 'the utopian not-yet of imagination' and the 'radical futurity' that cinema can engender. ${ }^{78}$

At times, the narrative momentum of 10 , rom romantica and Dimmi che destino avrò decelerates in order to portray the young Roma protagonists reaffirming their identities and aspirations, echoing the Blochian notions of subjective hope and self-comprehension. Marcias uses a montage of frontal close-ups of several Roma boys who receive football coaching from Giampaolo in his spare time. They are pictured individually as they voice their aspirations towards careers as lawyers and policemen, the verve of their enunciations transcending the objective reality of their sporadic scholastic attendance and the scale of prejudice that impedes any selfadvancement. Similarly, Gioia's voiceover in an early domestic sequence of $l o$, rom romantica foregrounds her thought processes as she contests the external labels that suffocate her true identity. A later sequence during a car journey to Rome visually externalizes the nature of Gioia's subjective hope, as her thoughts return to her family and particularly to her father who is visualized as less domineering and more supportive. This sequence is the culmination of a series of manifestations of Gioia's subjectivity that question the existing hegemonic forces that dictate who is accorded a determining voice within society, and the sequences also outline the contours of more utopian societal configurations located beyond the cinematic text.

But the nature of the dissensus that assumes a definitive form in the closing sequences of $l o$, rom romantica and Dimmi che destino avrò is based on liminality as a solution for their Roma protagonists, and it therefore does not constitute a total 'rupture' with the existing order. ${ }^{79}$ Halilovic's film concludes with Gioia now back in 
Turin, and once again behind a film camera. Her father - wearing a costume of overcoat and hat - is the object of her shot, and at its conclusion he mildly asks if his performance has been acceptable. A reverse shot shows that Gioia is now partnered - behind the camera, and, presumably, romantically - with a young Roma man whom her parents had contrived to present to her, and with whom she unexpectedly found common ground, in a different social context, before travelling to the Italian capital. The sense is of Gioia having advanced from the domestic sphere to garner the expertise necessary for her self-realization by tapping into a collective, shared intelligence ${ }^{80}$ with the consequence that the space of the common is expanded to accommodate her as an articulate 21st century Roma woman. Ultimately, however, she re-initiates contact with her community and its social network, but configures a position that enables her to distance herself from the restrictions of both cultures. Similarly, Dimmi che destino avrò concludes with Alina having returned to her employment in France, revitalized by her cultural immersion within her community, and her excursion into the realms of the Italian establishment brings the newly sensitized Giampaolo into her same liminal space, as he is welcomed to the wedding reception in the Roma camp. Both films therefore indicate a coming-to-voice of their female protagonists that is based on the hegemonic being assimilated into their developing emancipation, a pattern replicated by the more successful collaborations between the Roma and the outreach groups that operate in Italy.

\section{CONCLUSION: TOWARDS A CULTURAL AND POLITICAL MICRO-LEVEL EMANCIPATION}

In the main, $21^{\text {st }}$ century Italian fiction films can be exempted from the criticism that has traditionally been levelled at other cultural representations of the Roma, ranging from the eliciting of an 'enamoured fascination with Gypsy women', which lulia Hasdeu labels a 'fiction of the Other' (2008: 347), ${ }^{81}$ to the romanticization sometimes by academics - of nomadism as a form of resistance to the 'constraints of a settled life', a notion that Gay y Blasco dismantles in her analysis of the forcible transfers of Roma communities from one urban ghetto to another in countries such as Spain. ${ }^{82}$ Both in cinematic and in real-life political terms, the Roma are potentially very engaging subjects; as indicated in this essay, however, until well into the new millennium, the cinematic politicization of the Roma was insufficiently nuanced, relegating them to a marginalized socio-economic degradation which frequently became synonymous with endemic criminality. This representation effectively reinforced the engrained prejudices that lead nearly half the Italian population, when interviewed, to associate the Roma primarily with delinquency. ${ }^{83}$

Within the context of radical politics, despite the well documented contemporary problem of the 'lack of a revolutionary subject' and the ongoing search within Western Marxism for other groups 'who could play the role of the revolutionary 
agent, as understudies to the indisposed working class', ${ }^{84}$ the Roma are unsuited to this task. Although much could be learned from their community solidarity, which has resisted what Mazierska and Kristensen call the 'atomisation' of the working class ${ }^{85}$ and from their 'social capital' - the networks that afford them some protection from the welfare cuts that have impacted upon vulnerable groups across Europe, the Roma remain sceptical towards any form of organized political struggle and towards the ambiguities surrounding 'the rhetoric and instruments of emancipation' that are offered to them. ${ }^{86}$ Instead, recent Italian feature-length films such as Dimmi che destino avrò and lo, rom romantica have identified a latent emancipatory impetus within Roma women - the section of the Roma community with most to gain from changes to the status quo both within and beyond their communities. The films have, in effect, started to retrace the processes of identity politics from several decades ago, and to incorporate the Roma into them. The aim is to disrupt, in Rancière's terms, the consensus - which also now comprises several of the groups empowered by the rights movements of the past forty years - and to endow the Roma with a voice in the arena of culture, and ultimately within society.

1 I. Hancock, 'The 'Gypsy' Stereotype and the Sexualization of Romani Women' in Gypsies in European Literature and Culture, ed. by Valentina Glajar and Domnica Radulescu (New York: Palgrave Macmillan, 2008), pp. 181-91 (pp. 181-82). R. Lee, 'Roma in Europe; 'Gypsy' Myth and Romani Reality - New Evidence for Romani History' in Glajar and Radulescu, pp. 1-28 (pp. 3-4).

${ }^{2}$ Associazione 21 luglio, Rapporto annuale 2014 (Rome: Associazione 21 luglio, 2015), p. 12.

3 W. Hope, 'The Roma on Screen: Voicing the Counter-Hegemonic', Journal of Italian Cinema and Media Studies, 4.1 (2016), 65-83.

${ }^{4}$ In her presentation 'Confounding Racial Abjection and Ethnic Difference in Contemporary Italian Cinema' at the AAIS Annual Convention, Zurich, May 2014, Áine O'Healy implied that Tizza Covi and Rainer Frimmel's La pivellina (2009) could be categorized as a Roma film, but there is little to suggest that the characters - semi-itinerant circus entertainers, who are normally categorized separately from the Roma within regional education provision, for example - have Roma ethnicity or traditions.

${ }^{5} \mathrm{~K}$. Crenshaw, 'Mapping the Margins: Intersectionality, Identity Politics, and Violence against Women of Color', Stanford Law Review, 43.6 (1993), 1241-1299.

6 Crenshaw, 1243.

7 S. Žižek, 'How to Begin From the Beginning' in The Idea of Communism, ed. by Costas Douzinas and Slavoj Žižek (London: Verso, 2010), pp. 209-26 (p. 226).

8 J. Rancière, 'The Thinking of Dissensus: Politics and Aesthetics' in Reading Rancière, ed. by Paul Bowman and Richard Stamp (London/New York: Continuum, 2011), pp. 1-17 (p. 3).

9 J. Siebers, 'The Utopian Function of Film Music' in Marx at the Movies: Revisiting History, Theory and Practice, ed. by Ewa Mazierska and Lars Kristensen (Basingstoke: Palgrave MacMillan, 2014), pp. 46-61. I. Fraser, 'Bloch on Film as Utopia: Terrence Davies' Distant Voices, Still Lives' in Mazierska and Kristensen, pp. 62-81.

10 Rancière, 'The Thinking of Dissensus', p. 5. 
${ }^{11}$ N. Sigona and N. Trehan, 'The (re)Criminalization of Roma Communities in a Neoliberal Europe' in Racial Criminalization of Migrants in the $21^{\text {st }}$ Century, ed. by Salvatore Palidda (Farnham: Ashgate, 2011), pp. 119-32 (pp. 119-20).

12 Sigona and Trehan, p. 120.

13 Á. O'Healy (2010) 'Mediterranean Passages: Abjection and Belonging in Contemporary Italian Cinema', California Italian Studies 1.1 (2010), 1-19 (14). <https://escholarship.org/uc/item/2qh5d59c> [accessed 28 August 2015].

${ }^{14}$ M. Smith, Engaging Characters (Oxford: Clarendon Press, 1995), pp. 6, 83-84.

15 E. Di Blasi, 'Raid al campo nomadi, due arresti. Cancellieri: 'Violenza intollerabile”, La Repubblica, 11 December 2011.

<http://torino.repubblica.it/cronaca/2011/12/11/news/torino_ultr_bruciano_il_campo_rom_terrore_per_ uno_stupro_inventato-26420781/> [accessed 8 February 2016].

${ }^{16}$ C. Pasqualino, 'The Gypsies, Poor But Happy: A Cinematic Myth', Third Text, 22.3 (2008), 337-345 (340).

17 Pasqualino, 340-42.

${ }^{18}$ N. Dobreva, 'Constructing the 'Celluloid Gypsy': Tony Gatlif and Emir Kusturica's 'Gypsy' Films in the Context of New Europe', Romani Studies 17.2 (2007), 141-154 (147).

19 D. Iordanova, 'Mimicry and Plagiarism', Third Text, 22.3 (2008), 305-310 (307).

20 A. Capezzuto, 'Napoli, i due rom uccisi dalla camorra non siano vittime innocenti di serie B', I/ Fatto Quotidiano, 3 April 2015. <http://www. ilfattoquotidiano.it/2015/04/03/napoli-rom-uccisi-dalla-camorranon-siano-vittime-innocenti-serie-b/1562897/> [accessed 8 February 2016].

21 The ERRC distinguishes between informal/unauthorized camps which receive no institutional assistance; 'semi-formal' camps that are created by the Roma and subsequently recognized by local authorities; and the 'formal' camps ('campi attrezzati') where the Roma live in pre-fabricated containers and receive services such as water and electricity, while also being monitored. European Roma Rights Centre, Italia: rapporto del centro europeo per i diritti dei rom. Profilo del Paese, 20112012 (Budapest: ERRC, 2013), p. 8.

22 A. Geddes, 'II rombo dei cannoni? Immigration and the Centre-Right in Italy', Journal of European Public Policy, 15.3 (2008), 349-366 (361).

${ }^{23}$ Associazione 21 luglio, Rapporto annuale 2013 (Rome: Associazione 21 luglio, 2013), p. 9.

${ }^{24}$ Z. Bauman, Liquid Times: Living in an Age of Uncertainty (Cambridge: Polity Press, 2007), pp. 4950 .

${ }^{25}$ D. Harvey, Justice, Nature and the Geography of Difference (Oxford: Blackwell, 1996), p. 282.

${ }^{26}$ Hancock, p. 184.

27 D. Radulescu, 'Performing the Female Gypsy: Commedia Dell'Arte's 'Tricks' for Finding Freedom' in Gypsies in European Literature and Culture, ed. by Valentina Glajar and Domnica Radulescu (New York: Palgrave Macmillan, 2008), pp. 193-215 (pp. 196-97).

28 D. Iordanova, 'Welcome Pictures, Unwanted Bodies: Gypsy Representations in New Europe's Cinema' in Gypsies in European Literature and Culture, ed. by Valentina Glajar and Domnica Radulescu (New York: Palgrave Macmillan, 2008) pp. 235-240 (p. 239).

${ }^{29}$ Hancock, p. 188. 
30 Crenshaw, 1276.

${ }^{31}$ Crenshaw, 1276.

32 F. Jameson, The Political Unconscious (London: Routledge, 1989), pp. 85-87.

${ }^{33}$ Crenshaw, 1243.

${ }^{34}$ A. Oprea, 'Re-envisioning Social Justice from the Ground Up: Including the Experiences of Romani Women', Essex Human Rights Review 1.1 (2004), 29-39 (30).

35 Žižek, p. 226. The film's visual emphasis on the enduring dominance of Gioia's father is significant. This persists even though, socio-economically, Gioia's family have nothing in common with stereotypical media coverage of Roma destitution. The sequence showing her father selecting scrap materials to transport across Turin in his truck establishes him as a manual worker, while Gioia's involvement as an extra in a commercial, then as part of a local film troupe, and finally as the director of her own film work, positions her in the vicinity of Žižek's category of an intellectual labourer, a section of the $21^{\text {st }}$ century working class to be found in areas such as technology and cultural industries.

36 J. Rancière, Aesthetics and its Discontents, trans. by Steven Corcoran (Cambridge: Polity Press, 2009), p. 24.

37 P. Gay y Blasco, 'Picturing 'Gypsies': Interdisciplinary Approaches to Roma Representation', Third Text, 22.3 (2008), 297-303 (298).

38 Gay y Blasco, 298.

${ }^{39}$ M. Landy, Introduction to Imitations of Life - A Reader on Film and Television Melodrama, ed. by Marcia Landy (Detroit: Wayne State University Press, 1991), pp. 13-30 (pp. 14-15).

40 M. A. Doane, 'The Moving Image: Pathos and the Maternal' in Imitations of Life - A Reader on Film and Television Melodrama, ed. by Marcia Landy (Detroit: Wayne State University Press, 1991), pp. 283-306 (p. 286).

41 K. Crondahl and L. Eklund, 'Perceptions on Health, Well-Being and Quality of Life of Balkan Roma Adolescents in West Sweden', Romani Studies, 22.2 (2012), 153-173 (157).

42 Crondahl and Eklund, 157.

43 M. Rostila, Healthy Bridges: Studies of Social Capital, Welfare, and Health (Stockholm: Stockholm University, 2008), pp. 69-70. Associazione 21 luglio, Rapporto annuale 2013, pp. 12-14.

44 Rancière, Aesthetics and its Discontents, p. 24.

45 J. Rancière, 'Communists Without Communism?' in The Idea of Communism ed. by Costas Douzinas and Slavoj Žižek (London: Verso, 2010), pp. 167-177 (pp.176-77).

46 Rancière, 'Communists Without Communism?', pp. 167-68.

47 Rancière, 'Communists Without Communism?', p. 169.

48 Associazione 21 luglio, Rapporto annuale 2013, pp.12, 14.

49 E. Mazierska and L. Kristensen, Introduction to Marx at the Movies: Revisiting History, Theory and Practice ed. by Ewa Mazierska and Lars Kristensen (Basingstoke: Palgrave MacMillan, 2014), pp. 126 (p. 7). 
50 Mazierska and Kristensen, p. 8.

51 S. Corcoran, Introduction to Jacques Rancière, Dissensus: On Politics and Aesthetics, ed. and trans. by Steven Corcoran (London/New York: Continuum, 2010), pp. 1-24 (p. 6).

52 Žižek, pp. 214-15.

53 J. Rancière, 'Ten Theses on Politics' in Dissensus: On Politics and Aesthetics, ed. and trans. by Steven Corcoran (London/New York: Continuum, 2010), pp. 27-44 (p. 39).

54 J. Rancière, 'The Paradoxes of Political Art' in Dissensus: On Politics and Aesthetics, trans. Steven Corcoran (London/New York: Continuum, 2010), pp. 134-51 (p. 139).

55 Corcoran, p. 1.

56 Dimmi che destino avrò also subverts the notion of non-Roma individuals exploring Roma territory to gather knowledge for the benefit of a hegemonic majority. Early in the film, Giampaolo Esposito approaches a dwelling in a Roma camp to investigate a reported disappearance. Viewers are aligned visually and cognitively with him via a forward tracking shot which evokes the traditional impetus of the empowered, as an encounter is sought - on subaltern terrain - with the aim of extending hegemonic knowledge. However, once inside the Roma family's home, the bleak realism of the exterior camp shot is replaced by a long interior shot of an ornate, spacious living area. A centred, closed framing of a table where Giampaolo is seated centrally and alone - while members of the Roma family take their seats together laterally to observe him - inverts the dynamic of the sequence. Suddenly, Giampaolo's isolated bourgeois existence is under scrutiny, and it appears inadequate.

57 Corcoran, pp. 5-6.

58 Harvey, p. 101.

59 Harvey, p. 102.

60 Harvey, pp. 102-03.

${ }^{61}$ Harvey, p. 103.

${ }^{62}$ Rancière, 'The Thinking of Dissensus', p. 4.

63 b. hooks, 'Choosing the Margin as a Space of Radical Openness', referenced in Harvey, p. 103.

${ }^{64}$ Rancière, ‘Communists Without Communism?’, pp. 176-77.

65 Rancière, ‘Communists Without Communism?’, p. 167.

66 Corcoran, p. 21.

67 L. Piasere, Buoni da ridere, gli zingari, (Rome: CISU, 2006) referenced in M. Solimene, 'Undressing the Gagé Clad in State Garb: Bosnian Xoraxané Romá Face to Face with the Italian Authorities', Romani Studies 5, 23.2 (2013), 161-186 (167).

${ }^{68}$ Associazione 21 luglio, Centri di raccolta S.p.a., (Rome: Associazione 21 luglio, 2015).

69 Rancière, 'The Paradoxes of Political Art', pp. 134-51.

70 Corcoran, p. 19.

71 Rancière, Aesthetics and its Discontents, p. 25. 
72 P. Kruth, 'The Color of New York: Places and Spaces in the Films of Martin Scorsese and Woody Allen' in Cinema and Architecture, ed. by Francois Penz and Maureen Thomas (London: BFI, 1997), pp. 70-79. (pp. 72-73).

73 Associazione 21 luglio, Rapporto annuale 2014, p. 12.

74 Siebers, p. 47.

75 Siebers, p. 54.

76 E. Bloch, Literary Essays (Stanford: Stanford University Press, 1998), p. 62.

77 Fraser, p. 62.

78 Siebers, p. 59.

79 Rancière, 'The Paradoxes of Political Art', p. 143

80 Rancière, 'Communists Without Communism?', pp. 176-77.

${ }^{81}$ I. Hasdeu, 'Imagining the Gypsy Woman', Third Text, 22.3 (2008), 347-357 (347).

82 Gay y Blasco, 300.

83 Sigona and Trehan, p.123.

84 Žižek, p. 212.

85 Mazierska and Kristensen, p. 4.

${ }^{86}$ Solimene, 161-63. 